\title{
Multimodal HIIT is More Efficient Than Moderate Continuous Training for Management of Body Composition, Lipid Profile and Glucose Metabolism in the Diabetic Elderly
}

\author{
El Entrenamiento Multimodal es más Eficiente que el Entrenamiento Continuo Moderado para el \\ Manejo de la Composición Corporal, El Perfil de Lípidos y el Metabolismo de la Glucosa en \\ Adultos Mayores Diabéticos
}

Adalberto Louzada Júnior'; Josimar Mota da Silva ${ }^{1}$; Vernon Furtado da Silva²; Antônio Clodoaldo Melo Castro ${ }^{3}$; Rodrigo Eufrásio de Freitas ${ }^{3}$; Joy Braga Cavalcante ${ }^{3}$; Kennedy Maia dos Santos ${ }^{3}$; Ana Paula Azevedo Albuquerque ${ }^{4}$; Paula Paraguassú Brandão ${ }^{5}$; Maria de Nazaré Dias Bello ${ }^{6}$ Andrea Carmen Guimarães ${ }^{7}$; Mauro Cesar Gurgel de Alencar Carvalho ${ }^{8}$; Carlos Soares Pernambuco ${ }^{9}$ : Eder Benício Ramos Lima ${ }^{10}$; Renato Ramos Coelho ${ }^{10}$; César Augusto de Souza Santos ${ }^{10}$; Jani Cleria Pereira Bezerra $^{10}$; Estélio Henrique Martin Dantas ${ }^{11}$; Romeu Paulo Martins Silva ${ }^{12}$; Carolina Freitas da Silva ${ }^{12}$; Aristeia Nunes Sampaio $^{12}$ \& João Rafael Valentim-Silva ${ }^{3,13}$

LOUZADA JR., A.; DA SILVA, J. M.; DA SILVA-VERNON, F.; CASTRO, A. C. M.; DE FREITAS, R. E.; CAVALCANTE, B. J.; DOS SANTOS, K. M.; AlbUQUERQUE, A. P. A.; BRANDÃO, P. P.; BELlO, M. N. D.; GUIMARÃES, A. C.; CARVALHO, M C. G. A.; PERNAMBUCO, C. S.; LIMA, E. B. R.; COELHO, R. R.; SANTOS, C. A. S.; BEZERRA, J. C. P.; DANTAS, E. H. M.; ROMEU SILVA, P. M.; DA SILVA, C. F.; SAMPAIO, A. N. \& VALENTIM-SILVA, J. R. Multimodal HIIT is more efficient than moderate continuous training for management of body composition, lipid profile and glucose metabolism in the diabetic elderly. Int. J. Morphol., 38(2):392-399, 2020.

SUMMARY: The exercise could play a central role to the fat management and glucose metabolism what can be a critical role in the health status of diabetic people, but the high intense exercise remains with controversial data about their effects. To identify the effect of the multimodal high-intensity interval training on body composition, lipid profile, and glucose metabolism in elderly diabetics. Methods: Elderly diabetic individuals $(\mathrm{n}=48)$ were randomly divided in a Sedentary Control (SC) group, a Moderate-Intensity Continuous Training (MICT) group, and a High-Intensity Interval Training (HIIT) group. MICT and HITT were conducted over 60 days, 3x per week, with 40 minutes of exercise. Blood was collected prior to intervention, at four, and at eight weeks subsequently to assess glucose metabolism and lipid profiles. Body composition was determined before and after the intervention period. To verify the normality Kolmogorov-Smirnov statistical test was performed, followed by student " $t$ " test or two-way ANOVA with Bonferroni's post hoc test with significance of $5 \%$ the Cohen's f test to indicate the magnitude of the differences. HIIT significantly lowered cholesterol and triglyceride levels, and significantly lowered blood glucose and glycosylated haemoglobin levels ( $\mathrm{p}<0.05$ ). MICT and HIIT significantly increased levels of high-density lipoprotein, decreased total body mass and body mass index. HIIT resulted in significantly smaller waist circumferences, waist-to-hip ratios, and weight-to-height ratios over 60 days of training. HIIT is more effective than MICT for improving lipid and glycaemic profiles, decreasing body fat, and improving fat distribution elderly diabetics.

KEY WORDS: High-Intensity Interval Training; Body Composition Assessment; Glucose Metabolism; Dyslipidaemia; Diabetes; Elderly.

\footnotetext{
${ }^{1}$ Laboratory of Exercise Physiology of Lutheran Institute of High Education (ILES/ULBRA).

${ }^{2}$ Visiting Senior Professor at Physical Education Department of Federal University of Rondônia, Porto Velho, Rondônia, Brazil.

${ }^{3}$ Lecturer at Physical Educations Department of University Center UNINORTE, Rio Branco, Acre, Brazil.

${ }^{4}$ Movement Science Studies Group, of the Federal University of Amapá, Macapá, Brazil.

${ }^{5}$ Federal University of the State of Rio de Janeiro, Celso Lisboa University and Estácio de Sá University, Rio de Janeiro, Brazil.

${ }^{6}$ Laboratory of Biosciences of Humam Motrocity, of the University of Rio de Janeiro, Rio de Janeiro, University of the Amazon, Pará, Brazil.

${ }^{7}$ Federal University of São João Del Rei. Minas Gerais and Tiradentes University, Aracaju, Sergipe, Brazil.

${ }^{8}$ Universidad Católica del Maule, Talca, Chile. Laboratory of Human Motricity Sciecne, of the Federal University of the State of Rio de Janeiro, and Pedro II School, Rio de Janeiro, Brazil.

${ }^{9}$ Laboratory of Exercise Physiology, Estácio de Sá University, Cabo Frio, Rio de Janeiro, Brazil.

${ }^{10}$ Laboratory of Biosciences of Human Motricity, Tiradentes of the University, Aracaju, Sergipe, Brazil.

${ }^{11}$ Stricto Sensu Postgraduate Program in Nursing and Biosciences (PpgEnfBio) of the Federal University of the State of Rio de Janeiro (UNIRIO), Rio de Janeiro, Brazil and Post-graduation Program in Health and Environment (PSA), University Tiradentes (UNIT), Aracaju, Brazil.Laboratory of Biosciences of Human Motricity, University of the State of Pará, Pará, Brazil.

${ }^{12}$ Post Graduate Program in Health Sciences of the Federal Universit of Acre, Rio Branco, Acre, Brazil.Laboratory of Biosciecens dof Humam Motrocity, University of Rio de Janeiro, Rio de Janeiro, Brazil.

${ }^{13}$ Physical Education Department of the Federal University of Rondônia, Porto Velho, Rondônia, Brazil.
} 
LOUZADA JR., A.; DA SILVA, J. M.; DA SILVA-VERNON, F.; CASTRO, A. C. M.; DE FREITAS, R. E.; CAVALCANTE, B. J.; DOS SANTOS, K. M.; ALBUQUERQUE, A. P. A.; BRANDÃO, P. P.; BELLO, M. N. D.; GUIMARÃES, A. C.; CARVALHO, M C. G. A.; PERNAMBUCO, C. S.; LIMA, E. B. R.; COELHO, R. R.; SANTOS, C. A. S.; BEZERRA, J. C. P.; DANTAS, E. H. M.; ROMEU SILVA, P. M.; DA SILVA, C. F.; SAMPAIO, A. N. \& VALENTIM-SILVA, J. R. Multimodal HIIT is more efficient than moderate continuous training for management of body composition, lipid profile and glucose metabolism in the diabetic elderly. Int. J. Morphol., 38(2):392-399, 2020

\section{INTRODUCTION}

Exercise causes changes in physiology and morphology, as well as several other molecular, cellular, tissue and metabolic alterations in humans (Gibala et al., 2012). Several factors are responsible for these adaptations, including volume, intensity, frequency, type of exercise and the nature of exercise (Gillen et al., 2016).

High-intensity intermittent exercise (HIIT) is defined as exercises performed at high intensity with low-intensity recovery intervals (Gibala et al.), varying according to intensity, duration, recovery period, number of intervals, and other possible variations (Hwang et al., 2011).

There is evidence that intense, intermittent exercise stimulates physiological responses similar to those caused by continuous moderate-intensity exercise (Gibala \& McGee, 2008); in fact, studies have shown that it may be superior in some aspects (MacInnis \& Gibala 2017), a fact that inspires research on the subject.

Exercise has a significant acute effect on the rheological properties of blood. After exercise, there is an acute increase in plasma viscosity, as well as changes in the number and activity of immune cells (Hoff et al., 2015). Various soft tissues are acutely, subacutely or chronically affected by exercise, and adipose tissue can also be profoundly affected by exercise. Body composition, especially the amount and location of body fat, is associated with health parameters such as dyslipidaemias and hepatic steatosis, demonstrating the importance of controlling fat body mass (Lee et al., 2016; da Silva et al., 2016). Continuous or intermittent high-intensity exercises promote increased cardiovascular capacity (Gillen et al.; da Silva et al.), muscular hypertrophy (Egan \& Zierath, 2013) increased bone density (Nikander et al., 2010), and have been described as a viable alternative to traditional continuous and long-duration training.

Exercise also modifies lipid levels, generally by lowering levels of triglyceride, low-density lipoproteins (LDL) and by increasing levels of high-density lipoprotein (HDL) (Bruseghini et al., 2015). This fact alone would be enough to affirm that exercise promotes cardiovascular and metabolic benefits, although many other indicators have been documented, including decreased inflammation (Kawanishi et al., 2012) and improved human immune system activity (Hoff et al.), among other beneficial effects.

Several indices such as body mass index (BMI) and waist circumference (WC) have been proposed to determine associations between excess body weight and central adiposity as risk factors for the development of heart disease. This fact is central to the present study; furthermore several authors have demonstrated positive relationships between decreased body fat and central fat and risk factors associated with cardiovascular diseases in various populations mediated by exercise (Bruseghini et al.).

Other indicators have shown strong correlations with cardiovascular risk factors, including as waist-to-height ratio. Such studies have identified cut-off points of obesity as anthropometric indicators that discriminate coronary risks in various populations (Swainson et al., 2017).

Investigation of metabolic responses to various types of exercise can illuminate several parameters that determine its safety and effectiveness in various populations. Furthermore, stress can reveal additional physiological aspects of a disease. Analysis of glycaemic metabolism and lipid profiles in response to short-term intense exercise is essential for guidelines regarding safe and effective exercise, especially in the elderly.

Therefore, in the present study, we investigated the effect of high-intensity interval training on the body composition and lipid profile, and glucose metabolism in elderly individuals with diabetes.

\section{MATERIAL AND METHOD}

Study Type. This was a longitudinal experiment, because it involved a continuous time-scale of exposure to the experimental situation; it was quantitative, because the variables of interest were quantified; and it was quasi-experimental, because it had a voluntary group and the group was formed as a convenience sample.

Participants. This study was carried out in a Basic Health Unit of the municipal network in the East Zone of the City of Porto Velho, Rondônia, Brazil.

Inclusion criteria were as follows: clinical evaluation by a physician who attested to the subjects' physical health; ability to practice vigorous exercises; and type II diabetes as assessed by medical evaluation and biochemical markers (glucose and glycosylated haemoglobin). Type II diabetes mellitus was defined according to the recommendations of the American Diabetes Association (2014): HbA1c > $6.5 \%$ (levels between $5.7 \%$ and $6.4 \%$ were considered prediabetes). At the 6-month follow-up examination, $\mathrm{HbA} 1 \mathrm{c}$ levels were reassessed to determinate diabetes status and to select participants. The same physician who previously 
LOUZADA JR., A.; DA SILVA, J. M.; DA SILVA-VERNON, F.; CASTRO, A. C. M.; DE FREITAS, R. E.; CAVALCANTE, B. J.; DOS SANTOS, K. M.; ALBUQUERQUE, A. P. A.; BRANDÃO, P. P.; BELLO, M. N. D.; GUIMARÃES, A. C.; CARVALHO, M C. G. A.; PERNAMBUCO, C. S.; LIMA, E. B. R.; COELHO, R. R.; SANTOS, C. A. S.; BEZERRA, J. C. P.; DANTAS, E. H. M.; ROMEU SILVA, P. M.; DA SILVA, C. F.; SAMPAIO, A. N. \& VALENTIM-SILVA, J. R. Multimodal HIIT is more efficient than moderate continuous training for management of body composition, lipid profile and glucose metabolism in the diabetic elderly. Int. J. Morphol., 38(2):392-399, 2020.

treated all participants continued to follow them throughout the study. All participants were sedentary and had did not engage in habitual physical activity. None had employment with physical demands.

Inclusion criteria for athletic participants were as follows: (i) participation in > 1 exercise program prior to the study; and (ii) age $=$ or $<$ than 65 years. Exclusion criteria were as follows: (i) clinically manifest cardiovascular diseases; (ii) chronic alcoholism; (iii) unwillingness to give written informed consent, and (iv) other complication associated or not with diabetes that could serve as a confounding factor; (v) vital signs; and (vi) inability to exercise.

Forty-eight elderly volunteers of both sexes had a mean age of $69.55 \pm 14.32$ years, mean body mass $67.1 \pm$ $1.01 \mathrm{~kg}$, mean height $1.57 \pm 0.05$ meters and mean body mass index of $27.27 \pm 2.04 \mathrm{~kg} / \mathrm{m} \sum$. In follow-up, the patients were randomly divided in a Sedentary Control (SC) group that did not perform exercise protocols, a Moderate-Intensity Continuous (MICT) group that performed a walk protocol, and Multimodal High-Intensity Interval Training (HIIT) group. The latter two groups were subjected to 60 days of exercise, $3 \mathrm{x}$ per week for 40 minutes. To determine possible differences between groups, one-way ANOVA was performed, and no significant differences were noted for all parameters $(\mathrm{p}>0.05)$.

All volunteers gave consent to participate. The method was approved by the ethics and research council under CAAE number: 44907715.2.0000.5653 on 07/27/2015 to clinical and experimental approach. Finally, all subjects were monitored for medications, and during the intervention, medicine prescriptions were not modified.

Study design and procedures. Blood evaluations were performed at three time-points: prior to the start of the intervention period, and four and eight weeks afterwards, all of which coincided with the individual's routine monthly clinical consultation.

Three consultations were performed with the physician who attended to the patients, maintaining their monthly routine. These consultations occurred immediately before the intervention period, four weeks later, and at the end of the intervention. During these consultations, routine clinical measurements such as blood pressure, heart rate, cardiac auscultation, complete history taking, orthopaedic investigations and other medical investigations were carried out according to the monthly routine of clinical consultations.

These consultations served as support for the control of health conditions and for reporting intercurrences and adverse clinical events that might be related to the intervention proposed herein.

We measured levels of glucose, total cholesterol, triglycerides, HDL, LDL, lactate dehydrogenase, at baseline and after four and eight weeks of high-intensity intermittent exercise. These tests were performed using a Konelab 60i model analyser and Wiener Lab kits, following the protocol of the apparatus. The device was calibrated prior to performing the tests according to the manufacturer's manual.

At each collection, two blood samples were collected in EDTA tubes (4 $\mathrm{mL}$ vacutainer tube, BD Vacutainer, Franklin Lakes, NJ, USA) and stored in a refrigerated container $\left(4{ }^{\circ} \mathrm{C}\right)$ until measurement, which was performed in all cases within $1 \mathrm{~h}$ after venepuncture.

It should be emphasized that anthropometric and performance evaluations were only performed 60 days after the beginning of the intervention, because the literature categorically states that 30 days is insufficient for anthropometric and performance measurements to have changed sufficiently to show a difference, even in sedentary people.

Body compositions, as well as total and visceral body fat compositions were obtained using an In Body Digital Octapolar Platform (Soul, Korea). Waist circumferences were measured at the smallest point of circumference between the iliac crest and the last rib and hip with a flexible metal tape measure, with an accuracy of $0.1 \mathrm{~cm}$. Based on these measurements we calculated body mass index and waist-hip ratio (da Silva et al.; Valentim-Silva et al., 2016; de Oliveira et al., 2017).

Finally, we used 20 cardiac monitors to measure the heart rates during the walk protocol.

Training protocol: The walking protocol was performed over 40 minutes at $50 \%$ and $60 \%$ of the maximum heart rate measured by a Pollar Model FT1 in a 30 x 15-meter space adjacent to the Basic Health Unit of the municipal network in the East Zone of the City of Porto Velho, Rondônia, Brazil. A 5-minute cool down was carried out to promote calm using stretching techniques of very low intensity, similar to yoga.

A high-intensity interval training program was applied three days a week with an average duration of 40 minutes per meeting. All exercises were performed without equipment, using one's own body weight alone. Each exercise set was done against the clock at a ratio of 1:2, between activity and rest. 
LOUZADA JR., A.; DA SILVA, J. M.; DA SILVA-VERNON, F.; CASTRO, A. C. M.; DE FREITAS, R. E.; CAVALCANTE, B. J.; DOS SANTOS, K. M.; ALBUQUERQUE, A. P. A.; BRANDÃO, P. P.; BELlO, M. N. D.; GUIMARÃES, A. C.; CARVALHO, M C. G. A.; PERNAMBUCO, C. S.; LIMA, E. B. R.; COELHO, R. R.; SANTOS, C. A. S.; BEZERRA, J. C. P.; DANTAS, E. H. M.; ROMEU SILVA, P. M.; DA SILVA, C. F.; SAMPAIO, A. N. \& VALENTIM-SILVA, J. R. Multimodal HIIT is more efficient than moderate continuous training for management of body composition, lipid profile and glucose metabolism in the diabetic elderly. Int. J. Morphol., 38(2):392-399, 2020.

Daily, a standardized 5-minute warm-up with stretching exercises and calisthenics was performed. Subsequently, the main work-out was performed, consisting of forward-backward running, squats, push-ups, sit-ups, jumping jacks, walking lunges, dips, six-point support planks, pulse lunges, reverse lunges, skipping, mountain climbers, arm and leg raises, side steps, direction changing footwork and step-up-step-downs $(25 \mathrm{~cm})$.

Finally, a 5-minute cool down was carried out to promote calmness using stretching techniques as describe above. Each exercise was performed for 30,45 or 60 seconds for a recovery always $2 \mathrm{x}$ greater than the stimulus time. All classes had approximately 10 minutes of stimulation. During all moments of rest between one stimulus and another, the subject was free, yet encouraged to remain still and quiet awaiting the next stimulus in order to characterize a passive rest.

Energy expenditure monitoring. We calculated the caloric expenditure of an exercise as follows: Caloric expenditure $=\mathrm{VO} 2 \max *$ caloric equivalent $*$ time of the activity. Five kilocalories were used as the caloric equivalent. The caloric expenditure of both groups was similar in order to provide the same caloric cost per day of activity for MICT and HIIT.

6-Minute Walk Test. To determinate the VO2 Max, a 6MWT was performed. The test is conducted according to the guidelines of the American Thoracic Society (ATS), with adjustment of the track distance from 30 to $15 \mathrm{~m}$. Briefly, during the test, the patient should wear comfortable clothing. For patients requiring oxygen $(\mathrm{O} 2)$ during walking, they pushed their $\mathrm{O} 2$ tank support alone, as they would if they were at home. Before starting the test, we recorded heart rate $(\mathrm{HR})$, respiratory rate (RR), and blood pressure (BP). The formula used to calculate the VO2 Max was as follows:

Men: Distance TC6M $(\mathrm{m})=(7.57 \mathrm{x}$ height $\mathrm{cm})-(5.02 \mathrm{x}$ age $)$ - $(1.76 \mathrm{x}$ weight $\mathrm{kg})-309 \mathrm{~m}$;

Women: Distance TC6M $(\mathrm{m})=(2.11 \mathrm{x}$ height $\mathrm{cm})-(2.29 \mathrm{x}$ weight $\mathrm{kg})-(5.78 \mathrm{x}$ age $)+667.6$

Men: distance TC6M $(\mathrm{m})=(7.57 \mathrm{x}$ height $\mathrm{cm})-(5.02 \mathrm{x}$ age $)$ - $(1.76 \mathrm{x}$ weight $\mathrm{kg})-309 \mathrm{~m}$

Women: distance TC6M $(\mathrm{m})=(2.11 \mathrm{x}$ height $\mathrm{cm})-(2.29 \mathrm{x}$ weight $\mathrm{kg})-(5.78 \mathrm{x}$ age $)+667$

Statistical analysis. To verify the normality of the data, the Kolmogorov-Smirnov statistical test was performed. For analysis of the data, we performed the student " $t$ " test or two-way ANOVA with Bonferroni's post hoc test. All tests were performed with a significance of $5 \%$ using the program Prism Stat 5.0. To determine the effect size, the Cohen's test was applied using an online database at https:// www.socscistatistics.com/effectsize/default3.aspx.

\section{RESULTS}

HIIT improves lipid profiles, glucose levels and the glycated haemoglobin levels. Table I displays baseline data (P1), first comparison data (P2) and second comparison data (P3) for each of the three groups with respect to lipid profiles and glucose parameters. No significant differences were noted for the sedentary control group (SC) for any parameter across all time points. In the HIIT group, total cholesterol and triglycerides were significantly lower at P3 than at P1 ( $p<0.05$ ); LDL levels were significantly lower at P2 and P3 than at P1 ( $<<0.01)$; glucose and glycosylated haemoglobin levels were significantly lower at P3 than at P2 and P1; finally, HDL levels in the HIIT group were greater at P3 than at $\mathrm{P} 1$ or $\mathrm{P} 2$ ( $\mathrm{p}<0.01$ and $\mathrm{p}<0.05$, respectively). In the MICT group, HDL was significantly greater in P3 than in P1 ( p <0.05).

Cohen's d test showed that low-density lipoprotein in the MICT group had a small-magnitude decrease ( $\mathrm{f}=$ 0.17 ), while in the the HIIT group the decrease was of moderate magnitude $(\mathrm{f}=0.37)$. Similar behaviour was observed for high density lipoprotein, glucose, and glycosylated haemoglobin, where there was a small effect in the MICT group ( $\mathrm{f}=0.11, \mathrm{f}=0.13$, and $\mathrm{f}=0.17$ respectively) and the HIIT group showed a moderate effect ( $f=0.33, f=0.42$, and $f=37$ respectively).

Elderly individuals $(\mathrm{n}=48)$ were divided into three groups, SC (sedentary, $\mathrm{n}=16$ ) or (MICT, $\mathrm{n}=16$ ) and (HIIT, $\mathrm{n}=16$ ) subjected to multimodal high-intensity intermittent training. Blood samples were acquired to determine of lipid profiles and glucose metabolism, high density lipoprotein, low density lipoprotein on the baseline data (P1), after four weeks of interventions (first comparison data, P2), and eight weeks of intervention (second comparison data 2 (P3). Oneway ANOVA with a significance of $5 \%$ was used to indicate the possible differences between P1, P2 and P3. (*= difference vs $\mathrm{P} 1)$; and $(* *=$ difference vs $\mathrm{P} 2)$.

HIIT improves body composition and fat distribution on elderly diabetics. Figure 1 summarises baseline data (P1) and the first comparison point (P2) for each of the three groups with respect to body composition. Body composition had only two data points due of the suggest no less than 3 months to compare the body composition.

Mean mass in the SC group at baseline was $72.54 \pm$ $3.81 \mathrm{~kg}$; eight weeks later it was $71.91 \pm 3.71 \mathrm{~kg}$ (not significantly different; $p>0.05$ ) (Fig 1A). The mean weight of the MICT group at baseline was $73.65 \pm 3.51 \mathrm{~kg}$, and in 
LOUZADA JR., A.; DA SILVA, J. M.; DA SILVA-VERNON, F.; CASTRO, A. C. M.; DE FREITAS, R. E.; CAVALCANTE, B. J.; DOS SANTOS, K. M.; ALBUQUERQUE, A. P. A.; BRANDÃO, P. P.; BELLO, M. N. D.; GUIMARÃES, A. C.; CARVALHO, M C. G. A.; PERNAMBUCO, C. S.; LIMA, E. B. R.; COELHO, R. R.; SANTOS, C. A. S.; BEZERRA, J. C. P.; DANTAS, E. H. M.; ROMEU SILVA, P. M.; DA SILVA, C. F.; SAMPAIO, A. N. \& VALENTIM-SILVA, J. R. Multimodal HIIT is more efficient than moderate continuous training for management of body composition, lipid profile and glucose metabolism in the diabetic elderly. Int. J. Morphol., 38(2):392-399, 2020.

the comparison data, before eight weeks of walking exercise it was significantly lower $(70.54 \pm 3.55 \mathrm{~kg} ; \mathrm{p}<0.05)$. Mean mass of the HIIT group was $72.51 \pm 3.68 \mathrm{Kg}$ at baseline, and was significantly lower in the post-exercise period (68.91 $\pm 3.72 \mathrm{~kg} ; \mathrm{p}=0.0001)$.

Body Mass

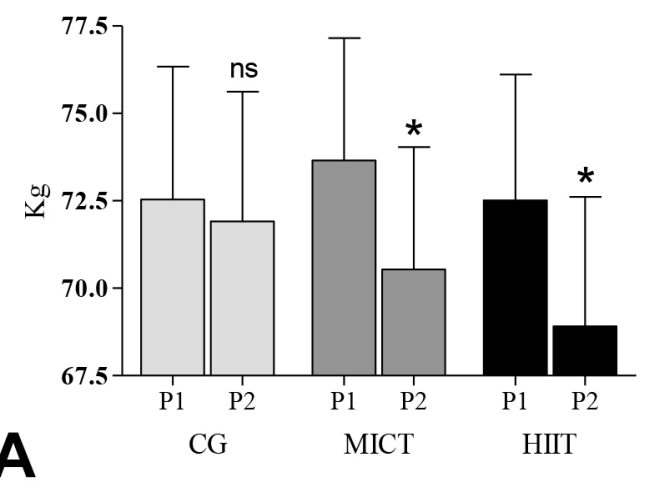

BAI

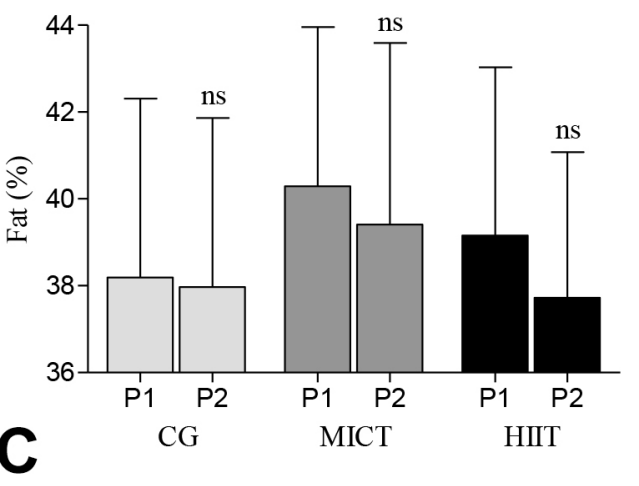

WHR

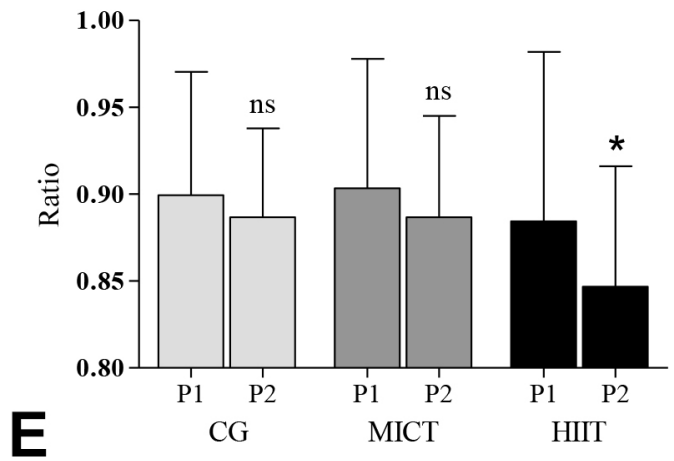

The body mass index (Fig. 1B) of the SC group at baseline was $29.02 \pm 3.11 \mathrm{~kg} / \mathrm{m}^{2}$ and in the comparison group it was not significantly different $\left(28.36 \pm 3.28 \mathrm{Kg} / \mathrm{m}^{2}\right.$; p $>0.05)$. In the MICT group, baseline BMI was $30.43 \pm 4.72$ $\mathrm{kKg} / \mathrm{m}^{2}$ and at the comparison point it was significantly lower

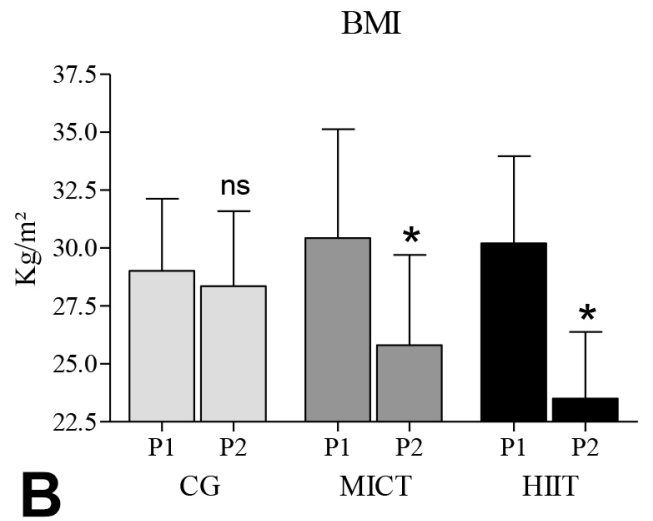

Waist Circunference

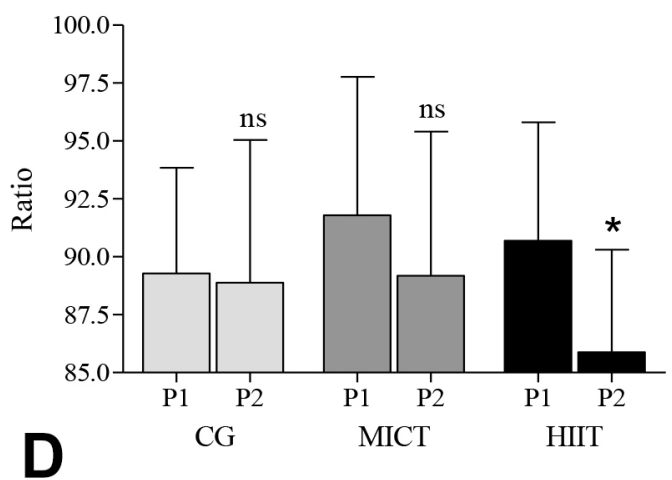

WCHR

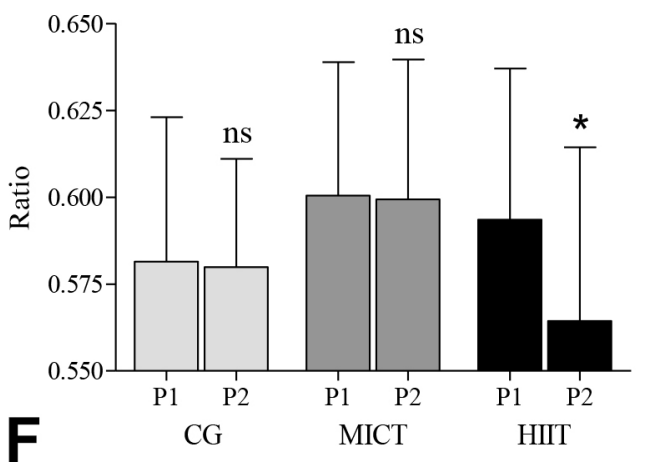

Fig. 1. Body Composition. Elderly individuals $(n=48)$ were divided into three groups, SC (sedentary, $n=16)$ or (MICT, $\mathrm{n}=16$ ) subjected to sixty days of walking, or (HIIT, $\mathrm{n}=16)$ subjected to multimodal high-intensity intermittent training. Body Mass (kg) (A), Body Mass Index (BMI) (B), Body Adiposity Index (BAI) (C), Waist Circumference (D), Waist-to-Hip Ratio (WHR) (E) and the Waist Circumference-to-Height Ratio (WCHR) (F) were determined or calculated on the baseline data (P1) and after eight weeks of interventions (first comparison data, P2). Student's t-test with a significance of $5 \%$ was used to indicate the possible differences between the pre and the post test. (A and $\mathrm{B} *=\mathrm{p}<0.05$ Post vs. Pre) $(\mathrm{C}, \mathrm{D}, \mathrm{R}$ and $\mathrm{F} \mathrm{NS}=\mathrm{p}>0.05$ Post vs. Pre). 
LOUZADA JR., A.; DA SILVA, J. M.; DA SILVA-VERNON, F.; CASTRO, A. C. M.; DE FREITAS, R. E.; CAVALCANTE, B. J.; DOS SANTOS, K. M.; ALBUQUERQUE, A. P. A.; BRANDÃO, P. P.; BELlO, M. N. D.; GUIMARÃES, A. C.; CARVALHO, M C. G. A.; PERNAMBUCO, C. S.; LIMA, E. B. R.; COELHO, R. R.; SANTOS, C. A. S.; BEZERRA, J. C. P.; DANTAS, E. H. M.; ROMEU SILVA, P. M.; DA SILVA, C. F.; SAMPAIO, A. N. \& VALENTIM-SILVA, J. R. Multimodal HIIT is more efficient than moderate continuous training for management of body composition, lipid profile and glucose metabolism in the diabetic elderly. Int. J. Morphol., 38(2):392-399, 2020

Table I. Biochemical, haematological and lipid parameters.

\begin{tabular}{llccc}
\hline Variables & & P1 & P2 & P3 \\
\hline \multirow{2}{*}{ Total } & SC & $189.3 \pm 42.8$ & $194 \pm 40.1$ & $192 \pm 39.9$ \\
Cholesterol & MICT & $199.1 \pm 40.3$ & $198 \pm 33.2$ & $201 \pm 48.9$ \\
& HIIT & $192.5 \pm 38.5$ & $179.4 \pm 77.5$ & $164.7 \pm 19.7^{*}$ \\
Triglycerides & SC & $186.1 \pm 33.2$ & $185.8 \pm 42.5$ & $188.3 \pm 39.5$ \\
& MICT & $180.9 \pm 40.7$ & $188.6 \pm 35.2$ & $192.8 \pm 41.7$ \\
& HIIT & $184.5 \pm 38.7$ & $176.5 \pm 38.7$ & $143.7 \pm 19.7 *$ \\
Low-Density & SC & $191.8 \pm 31.1$ & $194.7 \pm 39.5$ & $193.6 \pm 29.5$ \\
Lipoprotein & MICT & $193.6 \pm 19.4$ & $187.5 \pm 15.5$ & $166.4 \pm 17.1^{*}$ \\
& HIIT & $187.4 \pm 13.7$ & $172 \pm 14.6^{*}$ & $159 \pm 12.55^{*}$ \\
High-Density & SC & $39.5 \pm 4.4$ & $38.5 \pm 4.2$ & $39.8 \pm 4.6$ \\
Lipoprotein & MICT & $39.3 \pm 5.3$ & $41.6 \pm 7.1$ & $47.5 \pm 6.5^{*}$ \\
& HIIT & $41.5 \pm 3.7$ & $46.4 \pm 1.9 *$ & $53.5 \pm 2.97 * *$ \\
Glucose & SC & $177 \pm 12.3$ & $184 \pm 11.4$ & $181 \pm 14.2$ \\
& MICT & $184 \pm 10.2$ & $175 \pm 9.9$ & $144 \pm 11.5^{*}$ \\
Glycosylated & HIIT & $189.5 \pm 7.1$ & $154.5 \pm 6.7 *$ & $127.5 \pm 8.2^{*}, * *$ \\
Haemoglobin & MICT & $9.5 \pm 1.8$ & $9.9 \pm 2.1$ & $10.1 \pm 2.9$ \\
& HIIT & $9.2 \pm 2.2$ & $6.8 \pm 2.3^{*}$ & $5.9 \pm 1.5^{*}, * *$ \\
\hline
\end{tabular}

$\left(25.81 \pm 3.94 \mathrm{~kg} / \mathrm{m}^{2} ; \mathrm{p}<0.05\right)$. In the HIIT group, BMI was $30.21 \pm 3.76 \mathrm{~kg} / \mathrm{m}^{2}$ at baseline, and it was $23.51 \pm 2.88 \mathrm{~kg} /$ $\mathrm{m}^{2}$ in the comparison group $(\mathrm{p}<0.0001)$.

With respect to body adiposity index (BAI) (Fig. 1C) there were no significant differences in any group. With respect to waist circumference (Fig. 1D), in the SC group, baseline circumference was $89.28 \pm 4.56 \mathrm{~cm}$ and at the comparison point it was $88.88 \pm 6.17 \mathrm{~cm}(\mathrm{p}>0.05)$. In the MICT group, BAI was $91.79 \pm 5.98$ at baseline, and $89.18 \pm$ 6.23 at the comparison point ( $\mathrm{p}<0.05)$. Finally, in the the HIIT group, BAI was $90.69 \pm 5.12$ at baseline, and at the comparison point it was $85.88 \pm 4.42$, a significant difference after eight weeks of intervention $(\mathrm{p}<0.01)$.

In respect to waist-to-hip ratio (Fig. $1 \mathrm{E}$ ), in the $\mathrm{SC}$ it $0.89 \pm 0.07$ at baseline, and at the comparison point it was $0.88 \pm 0.05$ ( $p>0.05)$. In the MICT group, at baseline the value was $0.90 \pm 0.07$, and at the comparison point it was 0.88 \pm 0.05 ( $\mathrm{p}>0.05)$. In the HIIT group, it was $0.88 \pm 0.09$ at baseline and $0.84 \pm 0.06$ and at the comparison point $(\mathrm{p}<0.01)$.

With respect to waist circumference-to-height ratio (Fig. 1F), in the SC the value was $0.58 \pm 0.04$ at baseline and $0.57 \pm 0.03$ at the comparison point (not significant). A similar result was obtained in the MICT group, with $0.60 \pm$ 0.03 at baseline and $0.59 \pm 0.04$ at the comparison point. However, in the HIIT group, the value was $0.59 \pm 0.04$ at and $0.56 \pm 0.05$ at the comparison point HIIT $(\mathrm{p}=0.022)$.

The Cohen's d test showed that, with respect to body mass, MICT provoked a moderate-magnitude decrease ( $\mathrm{f}=$ $0.27)$, while HIIT provoked a large effect $(f=0.57)$. For
BMI, MICT had a moderate effect $(f=$ $0.31)$, while HIIT had a large effect $(f=$ $0.63)$.

\section{DISCUSSION}

The literature contains evidence of the benefits of exercise and sports on health in various populations (Egan \& Zierath; Hoff et al.; Lee et al.); however, there are no data regarding the effects of HIIT in elderly subjects. Nevertheless, these investigations are urgently needed. It has been shown that intermittent and high-intensity exercise generate several positive outcomes with respect to adult health (Karlsen et al., 2017), improving physical performance (Mijwel et al., 2018), in a manner similar to continuous exercise, although in very much less time. This may be seen as an advantage of HIIT over MICT; on the other hand, many factors need to be elucidated, including the effectiveness of HIIT in improving glucose metabolism, as well as improving lipid profiles in the diabetic elderly.

Therefore, the present study aimed to identify the effect of high-intensity interval training on the body composition, lipid profiles, and glucose metabolism in elderly individuals with type II diabetes, a fact poorly explored in the literature, because most studies have been performed with healthy young adults (Gibala et al.). For this purpose, we carried out a series of clinical, and biochemical investigations.

The data demonstrated here show that high-intensity intermittent training can be an effective strategy for the modification of factors related to quantitative and qualitative parameters of body composition, glucose metabolism, and lipid profile. There was no alteration in the daily self-reported nutrition routine (data not shown).

Several studies reported positive effects of MICT on the health of patients with diabetes. We too found that this exercise approach has several benefits, including decreasing total body mass and BMI (Figs. 1A and 1B, respectively) related to health benefits especially in those with metabolic disease such as diabetes. MICT was able in decrease fasting glucose, glycosylated haemoglobin, and low-density lipoprotein levels, and increased high-density lipoprotein levels (Table I). Taken together, these results suggest that MICT has positive effects on the health of aged people, in 
LOUZADA JR., A.; DA SILVA, J. M.; DA SILVA-VERNON, F.; CASTRO, A. C. M.; DE FREITAS, R. E.; CAVALCANTE, B. J.; DOS SANTOS, K. M.; ALBUQUERQUE, A. P. A.; BRANDÃO, P. P.; BELLO, M. N. D.; GUIMARÃES, A. C.; CARVALHO, M C. G. A.; PERNAMBUCO, C. S.; LIMA, E. B. R.; COELHO, R. R.; SANTOS, C. A. S.; BEZERRA, J. C. P.; DANTAS, E. H. M.; ROMEU SILVA, P. M.; DA SILVA, C. F.; SAMPAIO, A. N. \& VALENTIM-SILVA, J. R. Multimodal HIIT is more efficient than moderate continuous training for management of body composition, lipid profile and glucose metabolism in the diabetic elderly. Int. J. Morphol., 38(2):392-399, 2020.

accordance with results of several previous studies in healthy people (Wewege et al., 2018), and in patients with diabetes (Unamuno et al., 2018). However, the HIIT can be more effective than MICT in several respects. We found that intense interval exercise can provoke results more quickly, and with grater magnitude than MICT with respect to lipid and glucose metabolism (Table I) and to body composition (Fig. 1).

A recent study, showed changes in waist circumference and WHR, as was observed in the current study. These data are important in that they demonstrate that the intensity of the training can have a determining effect on measurements of body composition and physical performance. Both moderate and intense exercises applied intermittently are able to modify the parameters studied here, corroborating our results, though exhibiting different modifications (Marques et al., 2018).

Continuous long-term exercise may or may not also affect the body composition of healthy adults, including visceral fat, which has been strongly associated with increased risk of the development of cardiovascular diseases and cerebrovascular accidents. The results of the present study demonstrated a decrease in triglycerides, cholesterol and increases in HDL, a fact that has been reported in the literature. The decrease in central fat concentration is not always associated with a decrease in triglycerides, and even exercise alone was not always capable of modifying lipid parameters. However, recent studies in specific populations have demonstrated a positive relationship between anthropometric measurements of central adiposity and predictors of cardiovascular risk (Horowitz et al., 2018).

Competing endurance training modalities, showing decreases in body fat from resistance and endurance training performed on different days, with a correlation between this decrease in body fat, identifying a decrease in waist circumference with concentration of blood lipids and detected increased general physical capacity (Eklund et al., 2016).

The application of high-intensity exercises in elderly is a delicate issue because of the potential of lesions major adverse cardiovascular events that may be associated with the intensity of the exercise. Nevertheless, even though the entire program was inspired by a study carried out with young adults, none of the subjects reported any orthopaedic complications, or history of cerebrovascular accident, suggesting that it appears to be safe (data not shown). This could be very important data to support this approach in elderly people.
These results reported here suggesting that MICT and HIIT can decrease levels of glucose and glycosylated haemoglobin, and can improve the lipid profile relatively quickly, suggesting that HIIT may be an efficient tool to improve the health of the diabetic elderly. Nevertheless, care needs be taken with the HIIT approach, because studies have shown possible impairments in acute glucose control, producing hyperglycaemic events in diabetics (Bacopoulou et al., 2015; Karlsen et al.).

Conclusions and recommendations. MICT produced significant improvements in body weight, subcutaneous body fat, fat distribution, lipid profile, and glucose control; however, HIIT showed most effectiveness and quickly created a greater size effect for several variables. There was no evidence of health impairment in volunteers with any adverse event after sixty days of intermittent high-intensity training, suggesting that this training modality effectively improves the metabolic health of the diabetic elderly. We recommend that this approach be observed for a longer period of time with longer longitudinal interventions in order to assess the safety and efficacy of long-term HIIT for this particular population and to evaluate the effects of various daily and weekly exercise sessions in order to obtain ideal benefits for this population.

LOUZADA JR., A.; DA SILVA, J. M.; DA SILVA-VERNON, F.; CASTRO, A. C. M.; DE FREITAS, R. E.; CAVALCANTE, B. J.; DOS SANTOS, K. M.; ALBUQUERQUE, A. P. A.; BRANDÃO, P. P.; BELLO, M. N. D.; GUIMARÃES, A. C.; CARVALHO, M C. G. A.; PERNAMBUCO, C. S.; LIMA, E. B. R.; COELHO, R. R.; SANTOS, C. A. S.; BEZERRA, J. C. P.; DANTAS, E. H. M.; ROMEU SILVA, P. M.; DA SILVA, C. F.; SAMPAIO, A. N. \& VALENTIM-SILVA, J. R. El entrenamiento multimodal es más eficiente que el entrenamiento continuo moderado para el manejo de la composición corporal, el perfil de lípidos y el metabolismo de la glucosa en adultos mayores diabéticos. Int. J. Morphol., 38(2): 392-399, 2020.

RESUMEN: El ejercicio podría desempeñar un papel central en el manejo de la grasa y el metabolismo de la glucosa, lo que puede ser un papel crítico en el estado de salud de las personas diabéticas, pero el ejercicio intenso intenso sigue teniendo datos controvertidos sobre sus efectos. El objetivo del estudio fue identificar el efecto del entrenamiento multimodal de intervalos de alta intensidad sobre la composición corporal, el perfil lipídico y el metabolismo de la glucosa en diabéticos de edad avanzada. Los individuos diabéticos de edad avanzada $(n=48)$ se dividieron aleatoriamente en un grupo de control sedentario (SC), un grupo de entrenamiento continuo de intensidad moderada (MICT) y un grupo de entrenamiento de intervalos de alta intensidad (HIIT). MICT y HITT se realizaron durante 60 días, 3 veces por semana, con 40 minutos de ejercicio. Se recogió sangre antes de la intervención, a las cuatro y a las ocho semanas posteriormente para evaluar el metabolismo de la glucosa y los perfiles de lípidos. La composición corporal se deter- 
LOUZADA JR., A.; DA SILVA, J. M.; DA SILVA-VERNON, F.; CASTRO, A. C. M.; DE FREITAS, R. E.; CAVALCANTE, B. J.; DOS SANTOS, K. M.; ALBUQUERQUE, A. P. A.; BRANDÃO, P. P.; BELLO, M. N. D.; GUIMARÃES, A. C.; CARVALHO, M C. G. A.; PERNAMBUCO, C. S.; LIMA, E. B. R.; COELHO, R. R.; SANTOS, C. A. S.; BEZERRA, J. C. P.; DANTAS, E. H. M.; ROMEU SILVA, P. M.; DA SILVA, C. F.; SAMPAIO, A. N. \& VALENTIM-SILVA, J. R. Multimodal HIIT is more efficient than moderate continuous training for management of body composition, lipid profile and glucose metabolism in the diabetic elderly. Int. J. Morphol., 38(2):392-399, 2020.

minó antes y después del período de intervención. Para verificar la normalidad se realizó la prueba estadística de Kolmogorov-Smirnov, seguida de la prueba "t" de Student o ANOVA de dos vías con la prueba post hoc de Bonferroni con una significancia del $5 \%$ de la prueba $\mathrm{f}$ de Cohen, indicando las diferencias. HIIT redujo significativamente los niveles de colesterol y triglicéridos, además de reducir de manera importante los niveles de glucosa en la sangre y la hemoglobina glicosilada ( $\mathrm{p}<0.05$ ). MICT y HIIT aumentaron significativamente los niveles de lipoproteína de alta densidad, disminuyeron la masa corporal total y el índice de masa corporal. HIIT resultó en circunferencias de cintura significativamente más pequeñas, relaciones cintura-cadera y relaciones peso-altura durante 60 días de entrenamiento. HIIT es más efectivo que MICT para mejorar los perfiles de lípidos y glucémicos, disminuir la grasa corporal y mejorar la distribución de grasa en los diabéticos de edad avanzada.

PALABRAS CLAVE: Entrenamiento de intervalos de alta intensidad; Evaluación de la composición corporal; Metabolismo de la glucosa; Dislipidemia; Diabetes; Adulto mayor.

\section{REFERENCES}

American Diabetes Association. Diagnosis and Classification of Diabetes Mellitus. Diabetes Care, 37 Suppl. 1:S81-90, 2014.

Bacopoulou, F.; Efthymiou, V.; Landis, G.; Rentoumis, A. \& Chrousos, G. P. Waist circumference, waist-to-hip ratio and waist-to-height ratio reference percentiles for abdominal obesity among Greek adolescents. BMC Pediatr., 15:50, 2015.

Bruseghini, P.; Calabria, E.; Tam, E.; Milanese, C.; Oliboni, E.; Pezzato, A.; Pogliaghi, S.; Salvagno, G. L.; Schena, F.; Mucelli, R. P.; et al. Effects of eight weeks of aerobic interval training and of isoinertial resistance training on risk factors of cardiometabolic diseases and exercise capacity in healthy elderly subjects. Oncotarget, 6(19):16998-7015, 2015.

da Silva, R. A.; Lunardello, L. F. A.; de Oliveira, G. L.; de Olivera, T. A. P. \& Valentim-Silva, J. R. Ginástica geral pode melhorar a marcha e a capacidade cardiovascular de idosos. Rev. Bras. Med. Esporte, 22(4):306-10, 2016.

de Oliveira, G. L.; Perini de Oliveira, T. A.; Gonçalves, P. S. P.; Valentim-Silva, J. R.; Fernandes, P. R. \& Fernandes Filho, J. Body image and eating disorders in female athletes of different sports. J. Exerc. Physiol. Online, 20(2):4454, 2017.

Egan, B. \& Zierath, J. R. Exercise metabolism and the molecular regulation of skeletal muscle adaptation. Cell Metab., 17(2):162-84, 2013.

Eklund, D.; Häkkinen, A.; Laukkanen, J. A.; Balandzic, M.; Nyman, D. \& Häkkinen, K. Fitness, body composition and blood lipids following 3 concurrent strength and endurance training modes. Appl. Physiol. Nutr. Metab., 41(7):767-74, 2016.

Gibala, M. J. \& McGee, S. L. Metabolic adaptations to short-term high-intensity interval training: a little pain for a lot of gain? Exerc. Sport Sci. Rev., 36(2):58-63, 2008.

Gibala, M. J.; Little, J. P.; MacDonald, M. J. \& Hawley, J. A. Physiological adaptations to low-volume, high-intensity interval training in health and disease. J. Physiol., 590(5):1077-84, 2012.

Gillen, J. B.; Martin, B. J.; MacInnis, M. J.; Skelly, L. E.; Tarnopolsky, M. A. \& Gibala, M. J. Twelve weeks of sprint interval training improves indices of cardiometabolic health similar to traditional endurance training despite a five-fold lower exercise volume and time commitment. PLoS One, 11(4):e0154075, 2016.

Hoff, P.; Belav $\ddagger$ D. L.; Huscher, D.; Lang, A.; Hahne, M.; Kuhlmey, A. K.; Maschmeyer, P.; Armbrecht, G.; Fitzner, R.; Perschel, F. H.; et al. Effects of 60-day bed rest with and without exercise on cellular and humoral immunological parameters. Cell. Mol. Immunol., 12(4):483-92, 2015.
Horowitz, J. F.; Ortega, J. F.; Hinko, A.; Li, M.; Nelson, R. K. \& Mora-Rodriguez, R. Changes in markers for cardio-metabolic disease risk after only 1-2 weeks of a high saturated fat diet in overweight adults. PLoS One, 13(6):e0198372, 2018.

Hwang, C. L.; Wu, Y. T. \& Chou, C. H. Effect of aerobic interval training on exercise capacity and metabolic risk factors in people with cardiometabolic disorders: a meta-analysis. J. Cardiopulm. Rehabil. Prev., 31(6):378-85, 2011.

Karlsen, T.; Aamot, I. L.; Haykowsky, M. \& Rognmo, Ø. High intensity interval training for maximizing health outcomes. Prog. Cardiovasc. Dis., 60(1):6777, 2017.

Kawanishi, N.; Yano, H.; Mizokami, T.; Takahashi, M.; Oyanagi, E. \& Suzuki, $\mathrm{K}$. Exercise training attenuates hepatic inflammation, fibrosis and macrophage infiltration during diet induced-obesity in mice. Brain Behav. Immun., 26(6):931-41, 2012.

Lee, H. T.; Oh, H. O.; Han, H. S.; Jin, K. Y. \& Roh, H. L. Effect of mat pilates exercise on postural alignment and body composition of middle-aged women. J. Phys. Ther. Sci., 28(6):1691-5, 2016.

MacInnis, M. J. \& Gibala, M. J. Physiological adaptations to interval training and the role of exercise intensity. J. Physiol., 595(9):2915-30, 2017.

Marques, A. A.; Nogueira, T. R. B.; Silva, V. F.; de Oliveira, T. A. P.; de Oliveira, G. L.; Dantas, E. H. M.; de Pinho Gonçalves, P. S.; Filho, J. F.; Militao, A. G. \& Silva, J. R. V. Pilates plus cardiovascular training in body composition: effects of adding continuous cardiovascular training to the pilates method on adult body composition. MOJ Sports Med., 2(1):1-5, 2018.

Mijwel, S.; Backman, M.; Bolam, K. A.; Jervaeus, A.; Sundberg, C. J.; Margolin, S.; Browall, M.; Rundqvist, H. \& Wengström, Y. Adding high-intensity interval training to conventional training modalities: optimizing healthrelated outcomes during chemotherapy for breast cancer: the OptiTrain randomized controlled trial. Breast Cancer Res. Treat., 168(1):79-93, 2018.

Nikander, R.; Sievänen, H.; Heinonen, A.; Daly, R. M.; Uusi-Rasi, K. \& Kannus, P. Targeted exercise against osteoporosis: a systematic review and metaanalysis for optimising bone strength throughout life. BMC Med., 8:47, 2010 .

Swainson, M. G.; Batterham, A. M.; Tsakirides, C.; Rutherford, Z. H. \& Hind, $\mathrm{K}$. Prediction of whole-body fat percentage and visceral adipose tissue mass from five anthropometric variables. PLoS One, 12(5):e0177175, 2017.

Unamuno, X.; Gómez-Ambrosi, J.; Rodríguez, A.; Becerril, S.; Frühbeck, G. \& Catalán, V. Adipokine dysregulation and adipose tissue inflammation in human obesity. Eur. J. Clin. Invest., 48(9):e12997, 2018.

Valentim-Silva, J. R.; Costa, M. L.; de Oliveira, G. L.; de Oliveira, T. A. P.; Conceição, M. C. S. C. \& Dantas, E. H. M. High intensity exercise and flexibility of the lower limbs: dose-effect study. Rev. Bras. Med. Esporte, 22(4):311-4, 2016.

Wewege, M. A.; Ahn, D.; Yu, J.; Liou, K. \& Keech, A. High-intensity interval training for patients with cardiovascular disease-is it safe? A systematic review. J. Am. Heart Assoc., 7(21):e009305, 2018.

Corresponding author:

João Rafael Valentim-Silva

AC10 Avenue, $\mathrm{n}^{\circ} 1523$

Alto Alegre

Rio Branco

Acre

BRAZIL

Email: p.jrvalentim@gmail.com

Received: 16-07-2019

Accepted: 16-09-2019 